\title{
Epidemiology of mumps in the Netherlands
}

\author{
BY J. H. T. WAGENVOORT, M. HARMSEN, \\ BARRY J. KHADER BOUTAHAR-TROUW, \\ C. A. KRAAIJEVELD AND K. C. WINKLER \\ Laboratory of Microbiology, State University of Utrecht, \\ Catharijnesingel 59, 3511 GG Utrecht, The Netherlands
}

(Received 5 March 1980)

\section{SUMMARY}

In a Dutch population group neutralizing antibodies against mumps virus were determined by a plaque reduction technique, which proved reproducible, sensitive and specific. The results with sera of about 800 suburban children show that mumps is acquired at an early age with peak acquisition rates between the ages of four and six years. Over $90 \%$ have acquired mumps before the age of 14 years. More than $95 \%$ of about 1000 adults (18-65 years) have neutralizing antibodies. The relatively constant median titre suggests that antibodies persist during life.

During a family study 77 clinical and 18 subclinical cases were observed. In families with index cases the attack rate was $26 / 37=0 \cdot 71$. Eleven children (excluding six babies) escaped infection. The mean attack rate during the epidemic was $0 \cdot 30$. The mean titre of mumps neutralizing antibody is maximal during the first year after the disease but declines during childhood. Mothers exposed to mumps in the family occasionally showed a significant rise in titre. Some seronegative mothers remained seronegative after exposure.

\section{INTRODUCTION}

Mumps is, in general, a mild disease of children with parotitis as the main symptom. However, the virus spreads to many organs and occasionally may cause more serious lesions like meningitis and notably orchitis.

The age incidence of mumps varies with population density and communication. Morbidity reports are unreliable as $25-30 \%$ of mumps infections take a very mild or subclinical course (Feldman, 1976). According to the Center for Disease Control (CDC Report 1972) $50 \%$ of infections occur before primary school age and $90 \%$ before the age of 14 years. There is no sex difference. Analogous results were obtained in the United Kingdom (Mortimer, 1978). In the German Democratic Republic the incidence is maximal at the age of four to five years (Stelzner \& Talaska, 1972). Army camp epidemics suggested, however, that in some areas an appreciable fraction of children escape infection in childhood.

The sero-epidemiology of mumps has been studied by complement fixation (CF) (Liao \& Benenson, 1954), inhibition of haemagglutination (HI) (Black \& Houghton, 1967; Niederman et al. 1967) and virus neutralization (N) (Kenny et al. 1976). 
CF antibodies tend to diminish with time (Reed et al. 1967; Ennis et al. 1968) and HI may give false positives due to non-specific serum factors so that only titres of 10 or above are significant (Feldman, 1976). Furthermore, in CF and HI tests antibodies against parainfluenza viruses may crossreact with mumps antigen (Lennette et al. 1963; Hsiung, Isacson \& Tucker, 1963). Neither method, therefore, assures the detection of low levels of specific antibodies in immune adults, with mumps experience long ago.

Neutralizing antibodies are more suitable for sero-epidemiology as the test is very sensitive and more specific than CF or HI. Low antibody levels correspond well with immunity (Ennis, 1969; Hilleman, 1970) and crossreactions with antibodies against parainfluenza virus do not occur (Ennis et al: 1968; Grillner \& Blomberg, 1976).

Among the various methods for measuring neutralizing antibodies, the plaque reduction test (PRT) is the most sensitive (Kenny \& Schell, 1975). In the PRT for mumps antibodies of Sato et al. (1978) anti-human IgG was used which increased the titres about one hundredfold. However, the sensitivity is not increased by this method as a prozone phenomenon with undiluted serum precludes the detection of titres lower than those found without anti-human IgG. While neutralization tests have been used in vaccine trials (Weibel et al. 1967) and in sero-epidemiological studies (Kenny et al. 1976) the PRT has apparently not been used on a larger scale. This paper reports some data on the age incidence of mumps in the Netherlands as determined with the PRT. It also describes the results of a family study during a minor epidemic in an urban area.

\section{MATERIALS AND METHODS}

\section{Palettes}

A 24-well $(16 \times 17.8 \mathrm{~mm})$ palette (no. 3524, Costar Cambridge, U.S.A.) was used for the test. Virus dilutions were made in a 96-well palette (no. 3506). Palettes were re-used after washing in a washing machine and drying for $10 \mathrm{~h}$ in circulating air at $81^{\circ} \mathrm{C}$ with fully satisfactory results.

Cells

HEp-2 cells and Vero cells were equally satisfactory, though plaques were somewhat larger $(0 \cdot 5-1 \cdot 0 \mathrm{~mm})$ on Vero cells. Both cell lines were used as available.

\section{Media}

Autoclavable Eagle's medium (Yamane et al. 1968), supplemented with $5 \%$ heat-inactivated calf serum, $1 \%$ yeast extract, penicillin $(100 \mathrm{u} . / \mathrm{ml})$, streptomycin $(100 \mu \mathrm{g} / \mathrm{ml})$, gentamicin $(40 \mu \mathrm{g} / \mathrm{ml})$ and nystatin $(20 \mathrm{u} . / \mathrm{ml})$, was used throughout. The optimal concentration of Hepes buffer was $0.03 \mathrm{~m}$ for HEp-2 cells and $0.01 \mathrm{~m}$ for Vero cells. For Vero cells $0.06 \%$ sodium bicarbonate was also added. The optimal initial $\mathrm{pH}$ was $\mathbf{7 \cdot 2 - 7 \cdot 4}$. The overlay contained the same medium with $0.5 \%$ Oxoid agar no. 1 .

Virus isolated from a case of mumps on primary monkey kidney cells was 
passed on HEp-2 cells in Roux bottles. The sixth passage contained $5 \times 10^{5}$ plaque forming units (PFU) per $\mathrm{ml}$. It was diluted appropriately, stored at $-70^{\circ} \mathrm{C}$ in small portions and used for all tests.

\section{Diluent}

Phosphate buffered saline (PBS) with $1 \%$ peptone $(\mathrm{pH} \mathrm{7.2)}$ was used for all dilutions. Virus infectivity was stable in this diluent for at least $8 \mathrm{~h}$ at $37^{\circ} \mathrm{C}$.

\section{Reference antiserum}

An adult guinea-pig was infected intranasally with $10^{5}-10^{6} \mathrm{PFU}$ mumps virus. After 2 weeks the same dose was given intraperitoneally. The serum, drawn 3 weeks later, had a titre of 3000 and was diluted 200 -fold and stored in small portions at $-70{ }^{\circ} \mathrm{C}$.

Serum samples were obtained from about 1000 adult blood donors in the area near Utrecht and from children from the paediatric department of the University Hospital. The obstetric department provided 25 'paired' sera from cord blood and mother. Plasma sampled by collection of finger prick blood in heparin-coated tubes gave the same titres as serum of the same subject. About 450 such plasma samples were obtained from children in a family study (see below).

All sera and plasma samples were heat inactivated $\left(30 \mathrm{~min}\right.$ at $\left.56{ }^{\circ} \mathrm{C}\right)$ before use, as complement can affect mumps virus (Ginsburg \& Horsfall, 1949) and indeed caused plaque reduction in our experiments.

Antibody determinations by CF and HI were performed by the National Institute of Health, Bilthoven.

\section{Plaque reduction}

A virus dilution was adjusted so as to give $40-80$ plaques in each well. Threefold dilutions of heat-inactivated serum or plasma samples were prepared. Fifty $\mu \mathrm{l}$ of each undiluted or diluted sample were incubated with $50 \mu \mathrm{l}$ of virus dilution for $2 \mathrm{~h}$ at $37^{\circ} \mathrm{C}$ in a waterbath for neutralization. Other temperatures $\left(4^{\circ} \mathrm{C}\right.$, room temperature) or neutralization periods were less satisfactory. After incubation, the volume of the neutralization mixture was adjusted with diluent to $0.5 \mathrm{ml}$. From each mixture six replicates of $50 \mu \mathrm{l}$ were transferred to six wells onto cell monolayers and left for $1 \mathrm{~h}$ at room temperature for adsorption. After adsorption, $0.7 \mathrm{ml}$ of overlay medium was added to each well and the palettes were incubated in a humid atmosphere at $37^{\circ} \mathrm{C}$ for four to five days. The cells were then stained with $50 \mu \mathrm{l} 0.25 \%$ neutral red per well and again incubated at $37{ }^{\circ} \mathrm{C}$. Plaques were counted 24 to $48 \mathrm{~h}$ after staining. The serum dilution causing $50 \%$ plaque reduction was found by graphic interpolation. The titre is the inverse of this dilution. Titres are generally expressed as $\log _{10}$ values. The reference antiserum was included in each series of titrations. The standard error of day-to-day variation of the titre of this serum was 0.23 on a $\log _{10}$ scale. For about 100 serum samples titrated twice it was $0 \cdot 22$. Titres of at least $1(50 \%$ plaque reduction by undiluted serum mixed with an equal volume of virus) were taken as protective. 


\section{Virus isolation}

Swabs moistened in diluent were passed along the orifice of the parotic duct of both cheeks, put into $1 \mathrm{ml}$ of Eagle's medium and kept at $4{ }^{\circ} \mathrm{C}$ until incubation Part of the sample was titrated directly for mumps plaques on Vero cells. Another part of the sample was put into tubes with Vero cells. After 5 days the cells were tested for haemadsorption with guinea-pig red blood cells. In positive cases the isolation of mumps virus was confirmed by haemadsorption inhibition with reference serum. Tissue culture fluids of negative samples were transferred to fresh tubes on day 7 and the procedure was repeated.

\section{Family study}

In cooperation with three general practitioners a family study was started in Nieuwegein, a newly built satellite town of Utrecht, populated by people of different socio-economic backgrounds who had recently moved in from other areas. A letter asking for cooperation was sent to 370 families. From 239 families (65 \%) a positive response was received. The composition of the responder population $(r)$ and the non-responders $(n r)$ was about equal with regard to age of children (mean age $r=4 \cdot 1, n r=4 \cdot 2$ years $)$, mean number of children per family $(r=1.93$, $n r=1 \cdot 74)$, percentage of male children $(r=54 \%, n r=47 \%)$. Among 234 cooperating families 131 had one child, 75 two children and 33 more than two children.

In January 1978, all families were visited, mumps history was taken and scored on family cards and an initial blood sample was drawn from mothers and children. From then on mumps cases were reported. If the case was reported within two days, swabs were taken from patients and contacts. Four weeks later blood was taken from patients, mothers and siblings. In October 1978 a final blood sample was drawn from all seronegative children and their mothers. In February 1979 blood was taken from 48 children who had had serologically confirmed mumps during the epidemic between October 1977 and June 1978.

\section{RESULTS}

\section{Sensitivity and specificity}

The sensitivity of the PRT was tested on a number of paired sera from patients with mumps. A comparison with CF titres is given in Table 1. Neutralizing titres are already positive when clinical signs appear and the reconvalescence titres are in general higher than with CF.

The specificity was tested on sera from patients with a parainfluenza virus infection proved by virus isolation (Fig. 1). These paired sera showed a significant titre rise in CF or HI against parainfluenza virus I, II or III. No significant rise in mumps titre was detected during any of these parainfluenza virus infections. 
Table 1. Antibody titres in paired sera of patients with mumps, measured by complement fixation $(C F)$ and plaque reduction

$\begin{array}{cccc}\begin{array}{c}\text { Paired sera } \\ \text { of subject }\end{array} & \begin{array}{c}\text { Days of } \\ \text { illness }\end{array} & \begin{array}{c}\text { CF titres* } \\ \text { (mixed antigen) }\end{array} & \begin{array}{c}\text { Plaque reductic } \\ \text { antibody tit }\end{array} \\ 1 & 1 / 12 & 16 / 64 \dagger & 2 / 100 \\ 2 & 1 / 21 & 8 / 32(\mathrm{~V} \mathrm{ag}) & <1 / 80 \\ 3 & 2 / 12 & 16 / 64 \text { (V ag) } & 3 / 45 \\ 4 & 2 / 14 & <8 / 64 & 1 / 250 \\ 5 & 4 / 14 & 16 / 128(\mathrm{~V} \text { ag) } & <1 / 150 \\ 6 & 4 / 14 & 8 / 64 & 7 / 50 \\ 7 & 5 / 16 & <8 / 64 & 5 / 215 \\ 8 & 5 / 17 & 16 / 64 & 1 / 70 \\ 9 & 5 / 31 & 8 / 64 & <1 / 145 \\ 10 & 6 / 16 & 8 / 32 & <1 / 10 \\ 11 & 6 / 18 & 32 / 128 & <1 / 100 \\ 12 & 6 / 19 & 16 / 64 & 4 / 145 \\ 13 & 6 / 33 & 8 / 32 & <1 / 170 \\ 14 & 10 / 18 & 8 / 32 & 7 / 65 \\ 15 & 10 / 22 & 8 / 32(\mathrm{~S} \mathrm{ag}) & 40 / 125\end{array}$

* CF titres were kindly determined at the National Institute of Public Health, Bilthoven.

$\dagger$ First and second titre divided by dash.

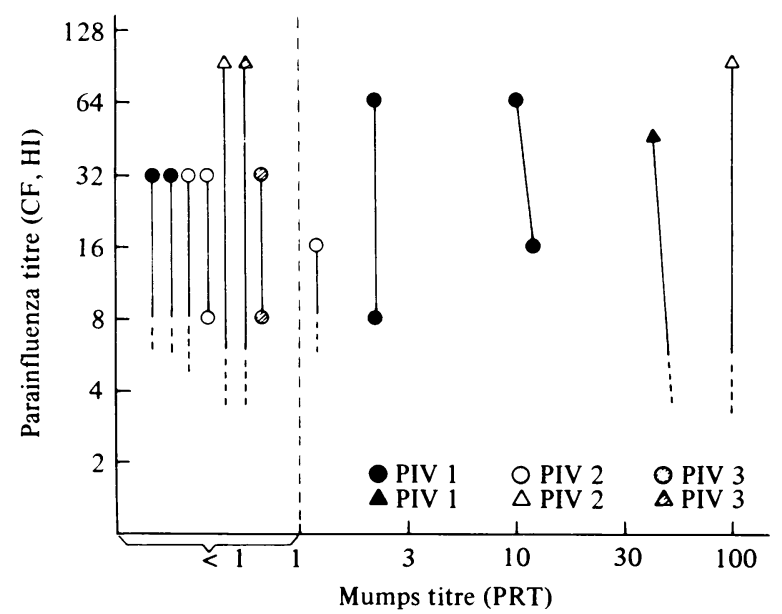

Fig. 1. Antibody titres against parainfluenza (circles for $\mathrm{CF}$, triangles for $\mathrm{HI}$ ) and mumps virus (PRT) in paired sera of patients with parainfluenza virus (PIV) infection.

\section{Titres in babies and infants}

In 25 serum pairs drawn from cord blood and mothers the titres are about equal (Fig. 2). The declining titres in the first months of life are plotted in Figure 3. In four cases, titres which had been negative before became positive in the second half of the first year of life, presumably due to subclinical infection. In two other cases antibodies 'persisted' at 15 months. 


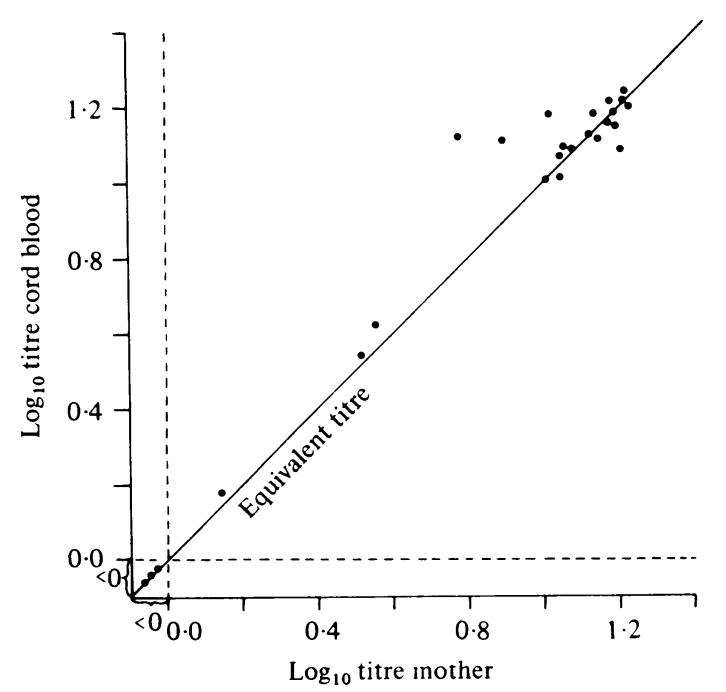

Fig. 2. Antibody titres (mumps, PRT) of neonates and their mothers.

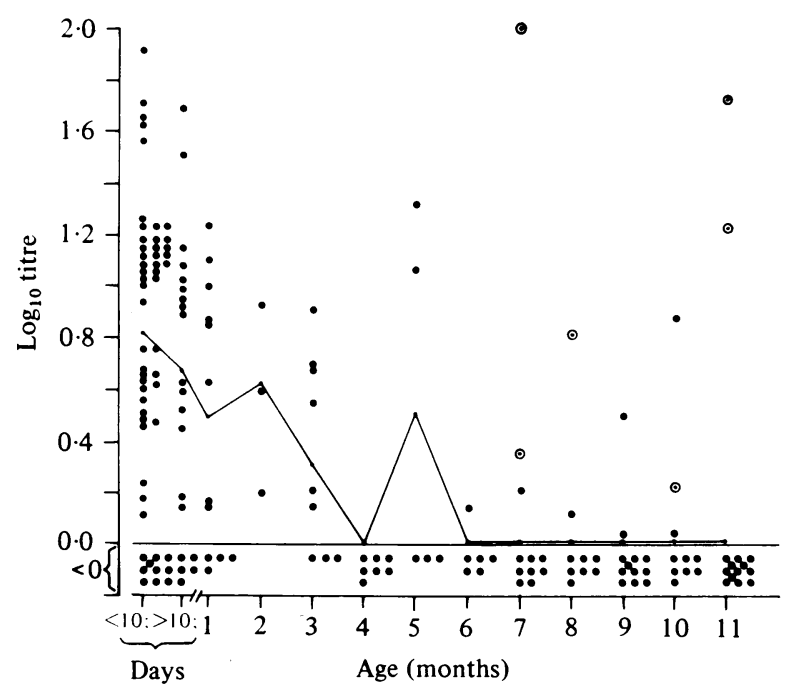

Fig. 3. Antibody titres (mumps, PRT) during the first year of life. 9 , Passive immunity; $\odot$, acquired immunity. The line represents the mean passive antibody titre.

\section{Age incidence of mumps}

Figure 4 shows for 800 children the percentage of seropositive children for ages from 0 to 16 years. The main rise of acquired immunity occurs at the age of 4 years. More than $50 \%$ had antibodies at the age of four and over $90 \%$ at the age of 14 . 


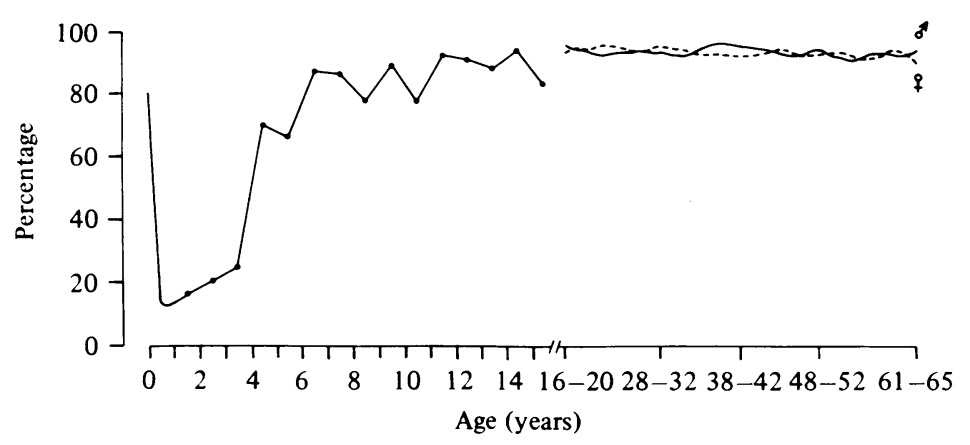

Fig. 4. Percentage of children and adults with antibodies against mumps. Values for children are given per year until 16 years (for detailed values from 0 -1 year see Fig. 3). For adults the progressive mean percentage for age groups of five years (16-20 up to 61-65 years of age) is shown. About 50 male and 50 female adult subjects per age group.

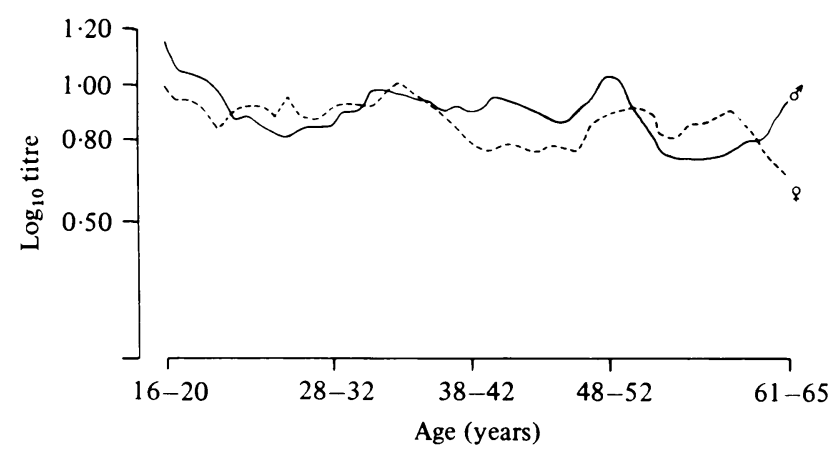

Fig. 5. Progressive mean titre of adults for age groups of five years (16-20 up to $61-65$ years of age).

\section{Neutralizing antibodies in adults}

About $95 \%$ of nearly 1000 adults have a positive titre in all age groups (16-20 up to 61-65 years of age) (Fig. 4), varying between just detectable (log titre of $0 \cdot 0-0 \cdot 1)$ to very high $(2 \cdot 0-2 \cdot 4)$. The distribution is about equal for males and females. Figure 5 shows that the mean antibody level remains fairly stable during adult life.

\section{Catalytic model}

When the catalytic model of Muench (1959) is applied to these data (Fig. 6), the fraction of the population with mumps specific antibodies $(y)$ increases with age according to $y=k\left(1-\mathrm{e}^{-r t}\right)$, where $k$ is the maximum fraction of subjects with mumps specific antibodies and $r$ the mean yearly acquisition rate. This was calculated over the first 16 years of life resulting in a mean rate of $0.176(y=0.95$ $\left(1-\mathrm{e}^{-0 \cdot 176 t}\right)$ ) (curve $\left.b\right)$. That exposure really begins at kindergarten age is reflected by the low mean rate $(0 \cdot 10)$ for children up to 4 years and the high mean rate 


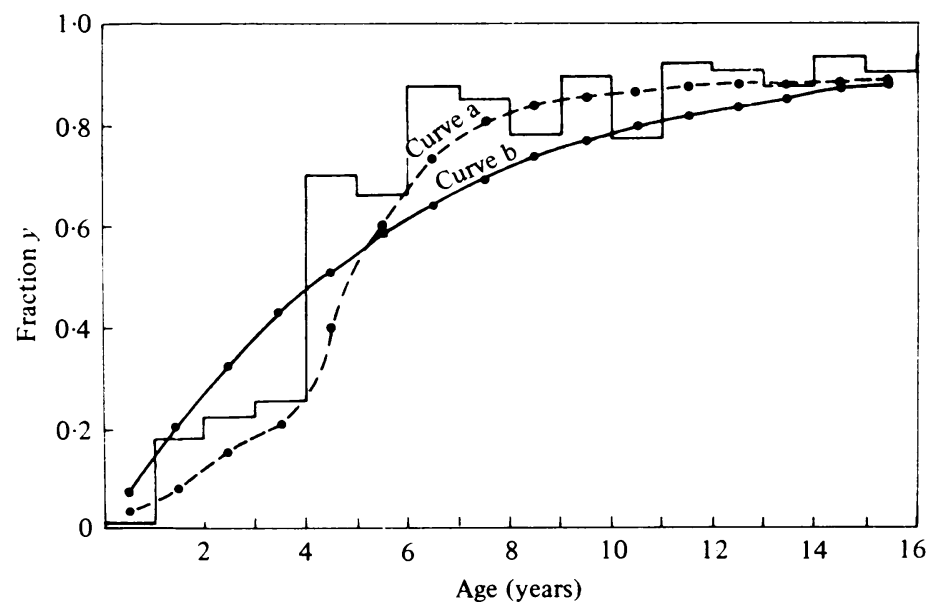

Fig. 6. Frequency of seropositive children according to a catalytic model. Full line: 0-16 years $(r=0 \cdot 176)$. Broken line: composite curve, 0-4 years $(r=0 \cdot 10), 4-7$ years $(r=0 \cdot 40)$ and $7-16$ years $(r=0 \cdot 10)$.

$(0 \cdot 40)$ for children aged 4-7 years. Presumably the rate decreases thereafter to $0 \cdot 1$ (curve a).

At a subclinical mumps attack rate of $19 \%$ (see family study below), the total fraction of subclinically acquired immunity would be $0 \cdot 18$ at the age of 15-16 years.

\section{Family study}

After the initial survey in January 197838 children in 25 families had clinical mumps $(37 \times$ parotitis, $1 \times$ meningitis $)$. Three children in these families showed seroconversion without symptoms, nine siblings (three babies) remained seronegative and may be considered as escapes.

A history of recent mumps parotitis (October 1977-January 1978) was noted for 39 children in 30 families and confirmed by the serum survey in January 1978. In these families the occurrence of five subclinical cases and five escapes could be deduced from the serological data.

In the serum survey of October 1978 ten seroconversions were found in children from families where mumps had not occurred. Table 2 summarizes these data and shows that 18 subclinical cases were observed in a total of 95 cases of mumps $(19 \%)$. The age distribution of these cases is given in Figure 7.

It is of course doubtful whether babies can be counted as escapes, as they might still be protected by (undetectable) antibody. However, four seroconversions in older babies and persisting antibodies in two babies of 12 months (Fig. 3) were found in the final survey showing beyond doubt that older babies can be infected. The subclinical course of these infections may be due to partial passive immunity.

The seasonal distribution of 77 clinical cases is given in Fig. 8. The distinct peaks in December 1977 and March 1978 can perhaps be interpreted as a reduced attack rate during the school holidays around Christmas. The epidemic ended in June 1978 and no mumps cases were observed during winter and spring 1979. 
Table 2. Clinical and subclinical mumps cases and escapes

\begin{tabular}{|c|c|c|c|c|}
\hline & \multicolumn{3}{|c|}{ Cases* } & \multirow[b]{2}{*}{ Families } \\
\hline & $\begin{array}{l}\text { Clinical } \\
\text { mumps }\end{array}$ & $\begin{array}{l}\text { Subclinical } \\
\text { mumps }\end{array}$ & Escapes & \\
\hline Reconstructed & 39 & $5(2)$ & $5(2)$ & 30 \\
\hline $\begin{array}{l}\text { Observed } \\
\text { (including final bloodsample) }\end{array}$ & 38 & $\left.\begin{array}{r}3(1) \\
10(3)\end{array}\right\} 13$ & $\left.\begin{array}{l}9(3) \\
3(1)\end{array}\right\} 12$ & $\begin{array}{r}25 \\
8\end{array}$ \\
\hline Total & 77 & $18(6)$ & $17(6)$ & 63 \\
\hline
\end{tabular}

* The number in parentheses gives the number of children younger than one year.

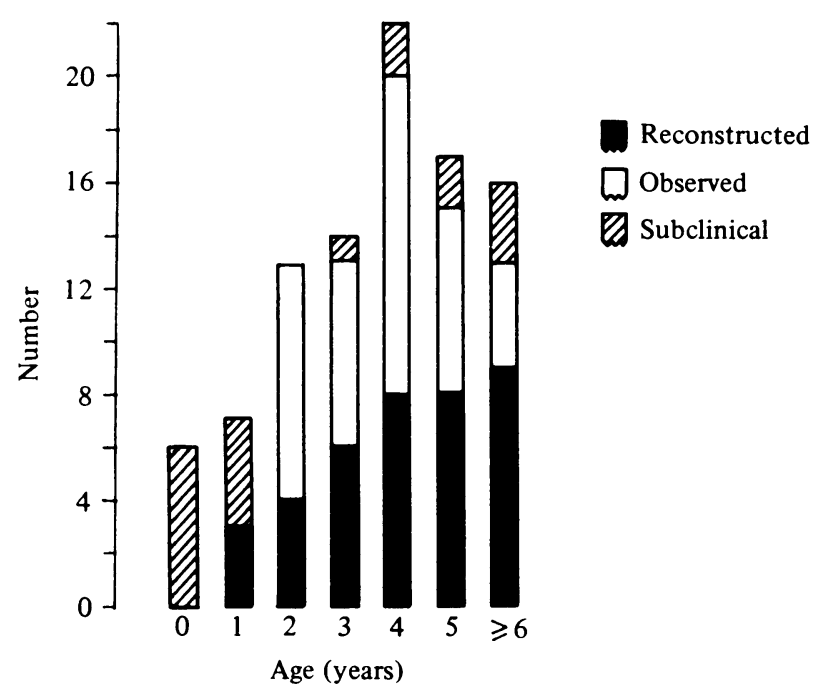

Fig. 7. Age distribution of clinical and subclinical mumps cases during the epidemic in the family study.

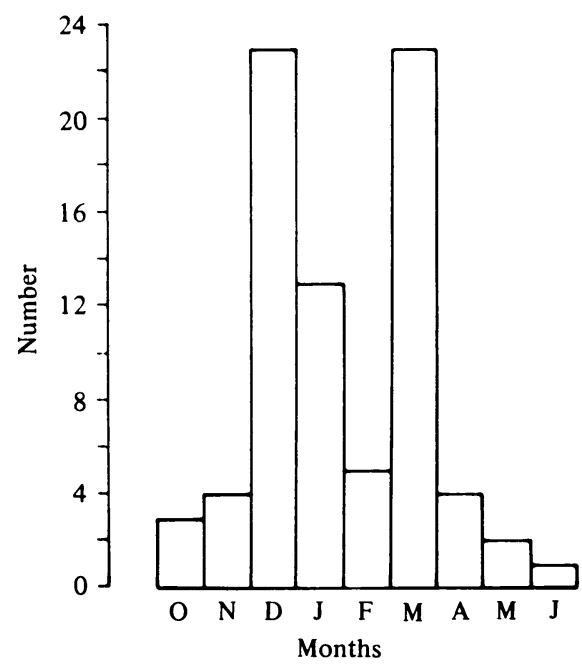

Fig. 8. Distribution of 77 clinical mumps cases per month during the epidemic. 


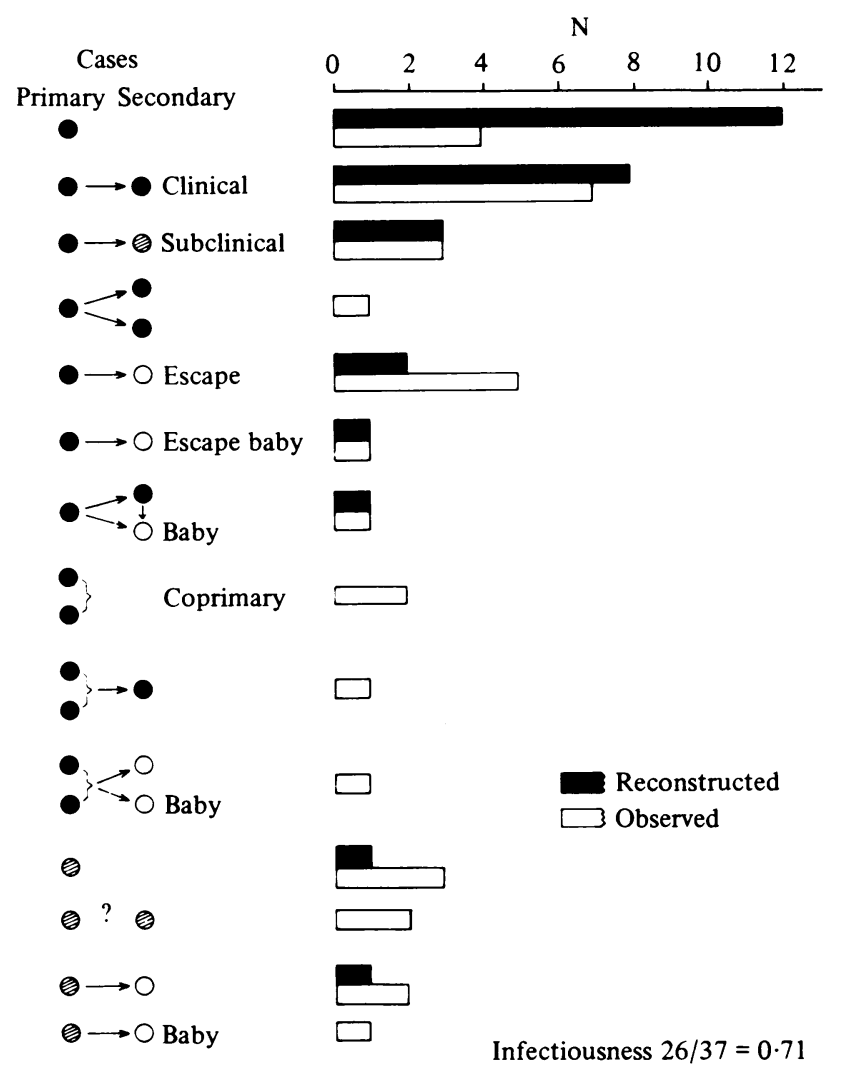

Fig. 9. Micro-epidemiology of mumps in families.

The micro-epidemiology of cases in the 63 families is given in Figure 9. The 41 primary cases in families with more children infected 26 out of 37 siblings (not counting six babies) resulting in a rate of infection in the family of $0 \cdot 71$. Most primary cases were of kindergarten age (4-5 years old).

During the epidemic 95 out of 290 seronegative children became seropositive, suggesting a mean acquisition rate in the population of $0 \cdot 30$. The mean age of infected children was four years, that of the 195 uninfected children was three years. Apart from the 17 escapes (Table 2 and Fig. 9) the latter belonged to families in which no mumps had occurred. They had not been infected outside the home (in kindergarten).

Virus isolation was possible only on the first three days of illness (Table 3). As many cases were reported rather late, isolations were few. In four cases direct plaque titration in the sample was possible, giving some idea about the quantity of virus present. Case no. 77 illustrates the decrease of virus on the cheek mucosa after the first day of illness.

Family members were sampled at the same time as cases and were presumably in the incubation period, when sensitive. No virus was isolated from contacts whether seropositive or seronegative. In two seropositive contacts symptoms of a trivial upper respiratory tract infection were observed. 
Table 3. Family members sampled for virus isolations

\begin{tabular}{|c|c|c|c|c|c|c|c|c|}
\hline \multirow[b]{3}{*}{ Case no. } & \multicolumn{3}{|c|}{ Cases } & \multicolumn{5}{|c|}{ Subling contacts } \\
\hline & \multirow{2}{*}{$\begin{array}{l}\text { Day of } \\
\text { illness }\end{array}$} & \multirow{2}{*}{$\begin{array}{l}\text { No. of } \\
\text { plaques } \\
\text { on swab }\end{array}$} & \multirow[b]{2}{*}{ Tubes } & & \multicolumn{4}{|c|}{ Serology } \\
\hline & & & & $n$ & Symptoms & + & - & Consequences \\
\hline 105 & 2 & 800 & ND & 2 & None & 2 & 0 & - \\
\hline 409 & 3 & 1560 & ND & 3 & None & 1 & 2 & $\begin{array}{l}\text { Mumps (410) } \\
\text { Baby escape }\end{array}$ \\
\hline 492 & 3 & 350 & ND & 2 & None & 1 & 1 & Subclinical \\
\hline 31 & 2 & - & + & 2 & None & 2 & 0 & - \\
\hline 303 & 4 & - & - & 2 & None & 1 & 1 & Subclinical \\
\hline 410 & 2 & - & - & 3 & None & 2 & 1 & Baby escape \\
\hline 692 & 4 & - & - & 2 & 1 cold & 2 & 0 & - \\
\hline 77 & 1 & - & + & 4 & $\begin{array}{l}3 \text { none } \\
1 \text { cold }\end{array}$ & 4 & 0 & - \\
\hline & 3 & - & - & & & & & \\
\hline & 6 & - & - & & & & & \\
\hline 117 & 3 & 40 & ND & 4 & $\begin{array}{l}2 \text { none } \\
2 \text { chronic } \\
\text { rhinitis }\end{array}$ & 2 & 2 & $\begin{array}{l}2 \text { escapes } \\
\text { ( } 1 \text { baby) }\end{array}$ \\
\hline
\end{tabular}

Table 4. Mean antibody titres of various (seropositive) groups

\begin{tabular}{|c|c|c|c|}
\hline Group & $n$ & Log mean titre & $P$ \\
\hline Adults & 964 & $0.92)$ & \\
\hline Children & & & $<0.001$ \\
\hline No recent mumps & 395 & $1 \cdot 15\}$ & \multirow{4}{*}{$<0.01$} \\
\hline Recent mumps & 95 & $1 \cdot 31$ & \\
\hline Children (4 weeks after illness) & 48 & $1 \cdot 46$ & \\
\hline Children ( 1 year after illness) & 48 & $1 \cdot 64$ & \\
\hline \multicolumn{4}{|c|}{ Children (seropositive January 1978) } \\
\hline Positive mumps history & 98 & $1 \cdot 39\}$ & \multirow{2}{*}{$<0.05$} \\
\hline Negative mumps history & 71 & $1 \cdot 27\}$ & \\
\hline \multicolumn{4}{|c|}{ Mothers (seropositive January 1978) } \\
\hline With seropositive child(ren) & 103 & $0.90\}$ & \multirow{2}{*}{$<0.025$} \\
\hline With seronegative child(ren) & 130 & $0 \cdot 78\}$ & \\
\hline
\end{tabular}

\section{Antibody titres}

Lines 1 to 3 in Table 4 show that the mean titre of children without recent mumps is higher than that of adults, but lower than that of children with recent mumps. The increase during the first year after mumps (lines 4 and 5) only means that the reconvalescent sample was often taken before the maximal titre. Together the data suggest that the decline in titre begins in childhood.

In the serological survey of January 1978 the mean titre of children with a positive history of mumps was slightly higher than that of seropositive children with a negative history (presumably by subclinical mumps, lines 6 and 7 ).

In the survey of January 1978 the mothers in 103 families where mumps had occurred had higher titres than mothers of 130 families where mumps had not yet occurred (lines 8 and 9 ). 
During the study a significant rise of individual titre between first and second sample was observed in seven out of 28 mothers of cases of mumps. Significance was accepted when the titre rise was at least 1.96 times the standard error of the difference, as calculated with the standard deviation $(0 \cdot 22)$ of day-to-day variation of the titration. Only four significant rises of titre were observed among 98 mothers of families wherein no mumps had occurred (chi square; $P<0.001$ ).

Out of 233 mothers 18 were seronegative in the initial as well as the final serum survey. Six of these had been exposed to mumps by one of their children, and four had been exposed twice during the study. Three of the ten exposed mothers had a positive and four a doubtful history of mumps in their own childhood. It is improbable that these ten mothers all escaped infection. They seem to have been protected by undetectable levels of antibody or by cellular immunity with or without antibodies.

\section{DISCUSSION}

The microneutralization test seemed reproducible sensitive and specific, as was observed by earlier authors. The main question is which of the titres can be accepted as protective. The results of Ennis (1969) and Hilleman (1970) suggest that any positive neutralization titre indicates immunity but the evidence depends on the absence of clinical mumps on exposure.

Generally, any specific titre in adults indicates the presence of memory cells which will be stimulated on reinfection and prevent clinical disease. The 'immunity' of ten seronegative mothers shows either that a PRT below one can protect or that cellular immunity without antibodies is of practical importance in humans.

The antibody prevalence in the population of our study suggests that mumps is acquired at an early age with peak acquisition rates between the ages of four and seven years (Fig. 4). It should be realized that the mean population density in the Netherlands is 409 inhabitants per $\mathrm{km}^{2}$ and that our results are derived mainly from children in a densely populated suburb of Utrecht. In a rural area the acquisition rate may be lower. At present only $12 \%$ of the Dutch population lives in such areas (CBS, 1978).

About $5-10 \%$ of mumps cases occur in (young) adults (CDC, 1978), but this might refer to less dense populations. In the United States the number of cases of mumps among army recruits decreased appreciably between World Wars I and II reflecting earlier infection with increasing population density (Feldman, 1976).

In our data about $5 \%$ of adults are seronegative because they escaped infection in childhood or possibly because antibody titres decreased below detectability. The relatively constant average titre (Fig. 5) suggests rather that mumps antibody persists quantitatively during life.

The titre rise in a number of mothers shows that reinfection can contribute to the persistence of antibodies. The importance of reinfection for the persistence of antibodies in the total population remains unknown. That immunity persists is evident from epidemiological data (Reed et al. 1967).

The attack rate in families with index cases was $0 \cdot 70$. The mean attack rate during the epidemic (about nine months) was $0 \cdot 30$. No mumps cases were observed 
by the general practitioners in the study during the next winter (1979). This is in a.cordance with the experience that mumps epidemics appear once in two or three years and would be in reasonable agreement with a mean yearly attack rate of 0.176 derived from the Muench model. The catalytic model presupposes a homogeneously mixed population. It is, however, obvious that for many (young) adults the chance of exposure to a child with mumps is remote. This suggests that the attack rate might well decrease with age and be already very low after school age for children in smaller families. A yearly attack rate of 0.40 between the ages of four and seven years, with a much lower rate before and after that age (Fig. 6, curve a), seems in better agreement with the observed data.

No cases of 'respiratory mumps' (Cooney, Fox \& Hall, 1975) were observed, either in children or babies with subclinical mumps (seroconversion without symptoms) or in seropositive contacts. Subclinical mumps as well as a titre rise in seropositive subjects implies local multiplication of mumps virus at the port of entry, presumably somewhere in the respiratory tract. Until a causal relation between mumps virus and respiratory symptoms has been soundly established, the term subclinical mumps is to be preferred.

We are grateful to Dr J. C. de Jong of the National Institute of Public Health (Bilthoven, The Netherlands) for help and advice and for the determination of CF and HI titres; to Mr F. J. van den Broek, Mrs R. van den Broek-Hartsuiker and Mrs B. Haverkamp, general practitioners, for introduction in their practice and to numerous individuals and several organizations for supplying blood samples, information or advice.

\section{REFERENCES}

Black, F. J. \& Hovghton, W. J. (1967). The significance of mumps hemagglutinin inhibition titers in normal populations. American Journal of Epidemiology 85, 101.

CBS, Statistisch Zakboek (1978). Centraal Bureau voor de Statistiek (Voorburg, The Netherlands).

CDC (Center for Disease Control) (1972). Mumps surveillance. Report no. 2.

CDC (Center for Disease Control) (1978). Mumps surveillance, July 1974-December 1976.

Cooney, M. K., Fox, J. P. \& Hall, C. E. (1975). The Seattle Virus Watch. VI. Observations of infections with and illness due to parainfluenza, mumps and respiratory syncytial viruses and mycoplasma pneumoniae. American Journal of Epidemiology 101, 532.

ENNIS, F. A. (1969). Immunity to mumps in an institutional epidemic: correlation of insusceptibility to mumps with serum plaque neutralizing and hemagglutination-inhibiting antibodies. Journal of Infectious Diseases 119, 654.

Ennis, F. A., Douglas, R. D., Stewart, G. L., Hopps, H. E. \& Meyer, H. M. JR. (1968). A plaque neutralization test for determining mumps antibodies. Proceedings of the Society of Experimental Biology and Medicine 129, 896.

Feldman, H. A. (1976). Mumps. In Viral Infections of Humans. Epidemiology and Control (ed. A. S. Evans), p. 317. London, New York: John Wiley \& Sons.

Ginsberg, H. S. \& Horsfall, F. L. (1949). A labile component of normal serum, which combines with various viruses. Neutralization of infectivity and inhibition of hemagglutination by the component. Journal of Experimental Medicine 90, 475.

Grillner, L. \& Blomberg, J. (1976). Haemolysis-in-gel and neutralization tests for determination of antibodies to mumps virus. Journal of Clinical Microbiology 4, 11.

Hilleman, M. R. (1970). Mumps vaccination. Modern Trends in Medical Virology 2, 241. 
Hsiung, G. D., Isacson, E. P. \& Tucker, G. (1963). Studies of parainfluenza viruses. II. Serological interrelationships in humans. Yale Journal of Biology and Medicine 35, 534.

Kenny, M. T., JACkson, J. E., Medler, E. M., Miller, S. A. \& Osborn, R. (1976). Agerelated immunity to measles, mumps and rubella in Middle American and United States children. American Journal of Epidemiology 103, 174.

KenNy, M. T. \& Schell, K. (1975). Microassay of measles and mumps virus and antibody in Vero cells. Journal of Biological Standardization 3, 291.

Lennette, E. H., Jensen, F. W., Guenther, R. W. \& Magoffin, R. L. (1963). Serologic responses to parainfluenza viruses in patients with mumps virus infection. Journal of Laboratory and Clinical Medicine 61, 780.

LiaO, S. J. \& Benenson, A. S. (1954). Immunity status of military recruits in 1951 in the United States. II. Results of mumps complement-fixation tests. American Journal of Hygiene 59, 273.

Mortimer, P. P. (1978). Mumps prophylaxis in the light of a new test for antibody. British Medical Journal ii, 1523.

Muench, H. (1959). Catalytic Models in Epidemiology. Cambridge, Mass.: Harvard University Press.

Niederman, J. C., Henderson, J. R., Opton, E. M., Black, F. L. \& Skvrnova, K. (1967). A nationwide serum survey of Brazilian military recruits. 1964. II. Antibody patterns with arboviruses, polioviruses, measles and mumps. American Journal of Epidemiology 86, 319.

Reed, D., Brown, G., Merrick, R., Sever, J. \& Feltz, E. (1967). A mumps epidemic on St George Island, Alaska. Journal of the American Medical Association 199, 967.

Sato, H., Albrecht, P., Hicks, J. T., Meyer, B. C. \& Ennis, F. A. (1978). Sensitive neutralization test for virus antibody. Archives of Virology 58, 301.

Stelzner, A. \& Talaska, W. (1972). Epidemiologische und serologische Mumps-analysen. Deutsches Gesundheitsuesen 27, 2083.

Weibel, R. E., Stokes, J. JR., Buynak, E. B., Whitman, J. E. \& Hilleman, M. R. (1967). Live, attenuated mumps-virus vaccine. 3 . Clinical and serologic aspects in a field evaluation. New England Journal of Medicine 276, 245.

Yamane, I., Matsuya, Y. \& Jimbo, K. (1968). An autoclavable powdered culture medium for mammalian cells. Proceedings of the Society of Experimental Biology and Medicine 127, 335. 